\title{
Application of Monopoly Media to Improve Readiness for Class VI Students in Facing the National Examination of Mathematics Learning
}

\author{
Agus Miftakus Surur ${ }^{1 *}$ (1)
}

${ }^{1}$ Institut Agama Islam Negeri Kediri, INDONESIA

*Corresponding Author: surur.math@gmail.com

Citation: Surur, A. M. (2022). Application of Monopoly Media to Improve Readiness for Class VI Students in Facing the National Examination of Mathematics Learning. International Journal of Pedagogical Development and Lifelong Learning, 4(1), ep2201. https://doi.org/10.30935/ijpdll/11419

\begin{abstract}
Try-outs are supported by adequate media. The result of the preliminary study is known that the try-out activity is only done as a general test so that we need a media that can be used in the try-out activity. In this study the media developed in the form of a monopoly. This research aims to develop a monopoly game media. This type of research is a development study using the Dick \& Carey development model. The target of this research is learning media as a practice of national exam questions which are packaged in the form of monopoly games and learning tools. Monopoly game media can be implemented for teaching and learning activities in the practice of national exam questions in the form of games.
\end{abstract}

Keywords: monopoly, try-out, Dick \& Carey

Received: 6 Jun. 2020 • Accepted: 29 Jul. 2020

\section{INTRODUCTION}

Mathematics is an organized structured science. This is because mathematics starts from an element that is not defined, then the element that is defined to the axiom / postulate and finally to the theorem. Amtematics concepts are arranged in a hierarchical, structured, logical, and systematic manner from the simplest concepts to the most complex concepts. Therefore, to study mathematics, the previous concepts that are prerequisites must be thoroughly mastered in order to understand the next topic or concept.

Mathematics is known as deductive science, because the process of finding truth (generalization) in mathematics is different from natural science and other sciences. The truth-seeking method used is a deductive method, it cannot be inductive. In natural science it is an inductive and experimental method. Although in mathematics the search for truth can begin with an inductive way, but so on the correct generalization for all circumstances must be proven by deductive means. In mathematics a generalization of the nature, theory or theorem can be accepted after the truth is proven deductively.

Mathematics is a deductive, formal, hierarchical science and uses symbolic language which has dense meanings. Because of differences in characteristics between mathematics and elementary school age children, mathematics will be difficult to understand by elementary school children if taught without regard to the thinking stage of elementary school children. A teacher should have the ability to connect between the world of children who have not been able to think deductively in order to understand mathematics that is deductive.

Mathematics which is a science with abstract objects and with development through deductive reasoning has been able to develop models that are examples of the system which in the end have been used to solve problems in everyday life. Mathematics can also change one's mindset into a mathematical, systematic, logical, critical and careful mindset. But this mathematical system is not in line with the stage of mental development of children, so what is considered logical and clear by adults in mathematics, is still a thing that does not make sense and make it difficult for children.

Elementary school children are children who are around the age of 7 to 12 years. According to Piaget, children around this age still think at the stage of concrete operations, meaning elementary students have not yet thought formally. The characteristics of children at this stage can understand logical operations with the help of concrete objects, can not think deductive, transitive thinking. Example: $2+2=4,4+2=6,6+$ $2=8,10+2=12$. This process can already be understood by students.

Other factors that must be considered in the process of learning mathematics, besides that the development stage of elementary school students 'thinking is not yet formal or still concrete is the diversity of elementary school students' intelligence as well as the number of elementary school students who are quite large compared to teachers who teach mathematics. Mathematics that is learned by elementary students can be used by elementary students for the benefit of their daily 
lives in the interests of their environment, to form logical, systematic, critical and careful thought patterns and finally can be used to learn other sciences.

Learning materials for class VI students who will face national exams require students to master as much material as they have learned. This will help students help with the questions during the national exam. As a practice preparation for the national exam exercises, held a try-out. Exams and try-outs have in common that is working on questions that are adapted to the national exam grid. It is hoped that students will be able to adapt to the exam so that when the national exam is smooth and correct in doing the questions.

Work on the questions must be made as comfortable as possible so that students do not have the pressure in working on and stay focused on the material. This needs to be done by teachers to innovate learning, especially to help students in preparing for the national exam. One of the innovations in learning is to bring / present learning media.

Learning media in mathematics is very minimal in existence, in contrast to science or social studies subjects that have concrete media in accordance with learning material. Presenting learning media in mathematics is a challenge for teachers. So that the material learned by students can be more embedded in students' thinking for longer. Media that is easy to use is a game media that is packaged by including learning material in it. When used in exam preparation, the media is a collection of practice questions packaged in the form of games. This is expected to make students more enthusiastic in doing practice questions.

Readiness is very important for students in preparing for the coming exam. If the tendency to act and people do it, then he will feel satisfied. As a result, he will not take any other action. The main thing is the existence of student actions to do something, in an effort to implant the material and stored longer. Satisfaction will appear as a result of knowing his abilities and avoiding a sense of sadness, because it has been packaged in the form of a game that prioritizes happiness. It also focuses the attention of students on only doing one main task, namely doing the practice questions.

One game that can be used is a monopoly game. The object of the game is to master all the plots on the board through the purchase, leasing and exchange of property in a simplified economic system. The purpose of the monopoly game is changed according to the objectives of learning, that is, students are able to answer as many practice questions, which in turn will add points in the game.

The existence of this monopoly game is very strategic to be applied to students in welcoming the national exam. Students become enthusiastic in working on problems and eventually become aware of the material. This is with the aim of obtaining high scores in the form of game points.

\section{RELATED RESEARCH}

\section{Henny Zurika Lubis, Anita Harahap}

Based on the analysis of student learning outcomes data it is known that there is an increase in student accounting learning outcomes using monopoly media. This can be known from the learning outcomes of each cycle I and II. At the time of the pre-test there were 15 (42.85\%) students who had completed their study with an average grade of students was 52.74, while in the first cycle there were $23(65.71 \%)$ people who completed with an average student grade of 66.2 , and in the second cycle the number of students who finished learning became 31 students $(88.57 \%)$ with an average student score of 81.51 , the increase in the average value in cycle I to cycle II was 15.31 points.

\section{Arif Susanto, Raharjo, Muji Sri Prastiwi}

Based on the analysis of the results of research and discussion, biology monopoly game media have been produced on the topic of cells. Monopoly game media as a learning media for high school students of class XI IPA on cell material get theoretical validity with the feasibility aspects of the media format $90 \%$, the visual aspect $94 \%$, the function / quality aspects of the media $92.86 \%$, and the media clarity aspect $88.33 \%$ . Based on the description, the biology monopoly game media is feasible and can be used in biology learning activities on cell topics.

\section{Zuhri Firdaus, Siti Zubaidah, Sunarmi}

The percentage value of media assessment of the monopoly science of food digestive system material by media experts, material experts, field practitioners and students respectively is 86 ; $85.6 ; 85 ; 85$ with a very high level of validity. Overall conclusion, the media game of science monopoly is appropriate to be used to help students learn the food digestive system material.

\section{Budi Adi Prayogo}

The application of monopoly game media is able to increase student learning outcomes, which initially averaged 63.85 to 89.19 or had an increase in gain of 25.33 with moderate criteria and n-gain of 0.73 with high criteria of hypothesis.

The results of the above studies have in common with this study:

a. Using monopoly media as learning media.

b. Able to improve the ability of students (students), so that in this study it is expected to be able to improve students' abilities.

c. Manipulate the game adapted to learning.

While the novelty in this study are:

a. The material presented is material for preparation of national examinations that are adjusted to the grid.

b. Can be done in individuals or in groups.

\section{LEARNING INNOVATION}

\section{Research Design}

This research is a type of development research. Development Research is an attempt to develop an effective product for school use and not test theory (Gay, 1991). Meanwhile, according to Seals and Richey (1994) defines development research as a systematic assessment of the design, development and evaluation of programs, processes and learning products.

\section{The Dick \& Carey Model}

Broadly speaking, learning media development activities consist of three major steps that must be passed, namely planning, production and assessment activities. According to Sadiman (2009) the sequence of steps that must be taken in developing a media program into 6 (six) steps, namely (1) Analyzing the needs and characteristics of students means that we must know the gap between the abilities, skills and attitudes of students we want with the abilities, skills and the attitude they have now. (2) Formulating instructional objectives (Instructional objectives) using operational and distinctive, (3) Formulating detailed 
items that support the achievement of objectives; (4) Developing tools to measure success, 5) Writing media scripts; (6) Conducting tests and revisions aimed at evaluating the effectiveness and efficiency of instructional media. Educators need to develop teaching materials into teaching materials or media according to the needs in the learning implementation plan to make it easier for teachers to teach material to students.

The ability of teachers to develop related teaching media in the attachment to Minister of Education Regulation Number 16 of 2007 concerning Academic Qualification Standards and Teacher Competence. Teachers as professional educators are expected to have the ability to develop teaching materials (media) according to the mechanism by taking into account the characteristics and social environment of students (Ministry of National Education, 2010). Is a system design model that is often used in extensive research and development. The steps that must be done are shown in Figure 1.

\section{Analysis of needs and goals}

Conduct a needs analysis to determine the objectives of the program or product to be developed. This needs analysis activity researchers identified priority needs that immediately need to be met. Class VI students will conduct a series of National Examination exercises in the form of try-outs. Try-outs are generally carried out by means of the test as usual. This will make the ability of students will tend to remain because there is no special treatment. Based on that, there is a need for practice tests in other forms that students will be interested in doing and can also increase the spirit of learning by making try-out games.

\section{Analysis of learning}

Learning in try-outs is students answering questions that are in accordance with the national exam grid. So this game will also prioritize the exercises in learning and games.

\section{Learner and context analysis}

This analysis can be carried out simultaneously with the analysis of learning above, which contains training material for national exams from year to year. In this study the questions used are national exam questions from 2014 to 2018.

\section{Formulate performance goals}

The game used is monopoly. Students will play a monopoly in which the previous year's national exam questions have been entered. Students understand the game system so that learning games can be done optimally.

\section{Developing instruments}

This monopoly game has been modified so that it is suitable for use in learning. In addition, the materials in which are national exam questions as a substitute for practice doing the questions. Some of the questions were changed according to the current national exam grid. One example of a question that was changed from the original question text is the question asked by FPB, changed to the difference between the $\mathrm{KPK}$ and FPB, so that in one problem students will learn to look for the $\mathrm{KPK}$ and FPB.

\section{Develop learning strategies}

This monopoly game is carried out in several modifications. The game is similar to monopoly games in general. If you have never played a monopoly, it doesn't matter because the steps in the game are easy to understand and do. One modification of the original monopoly game is to abolish the research system of houses and hotels, reducing the types of money to 3 types initially 9 types.

\section{Develop and choose learning materials}

This monopoly is made of paper, the non-paper part is a piece (object that is moved as a puppeteer). The paper used is A3-sized photo paper and manila paper. This monopoly media consists of playing boards, area cards, play money (substitute points), dice, and pieces

a. This monopoly game equipment there are several manipulations, adjusted for learning needs:

1) The shape of the board is a hexagon from what was originally square. This is to accommodate more players on one board, up to 6 players, which initially only have a maximum of 4 players.

2) Number of board boxes from 40 boxes to 30 boxes.

3) There are 6 areas in each corner which were originally 4 areas.

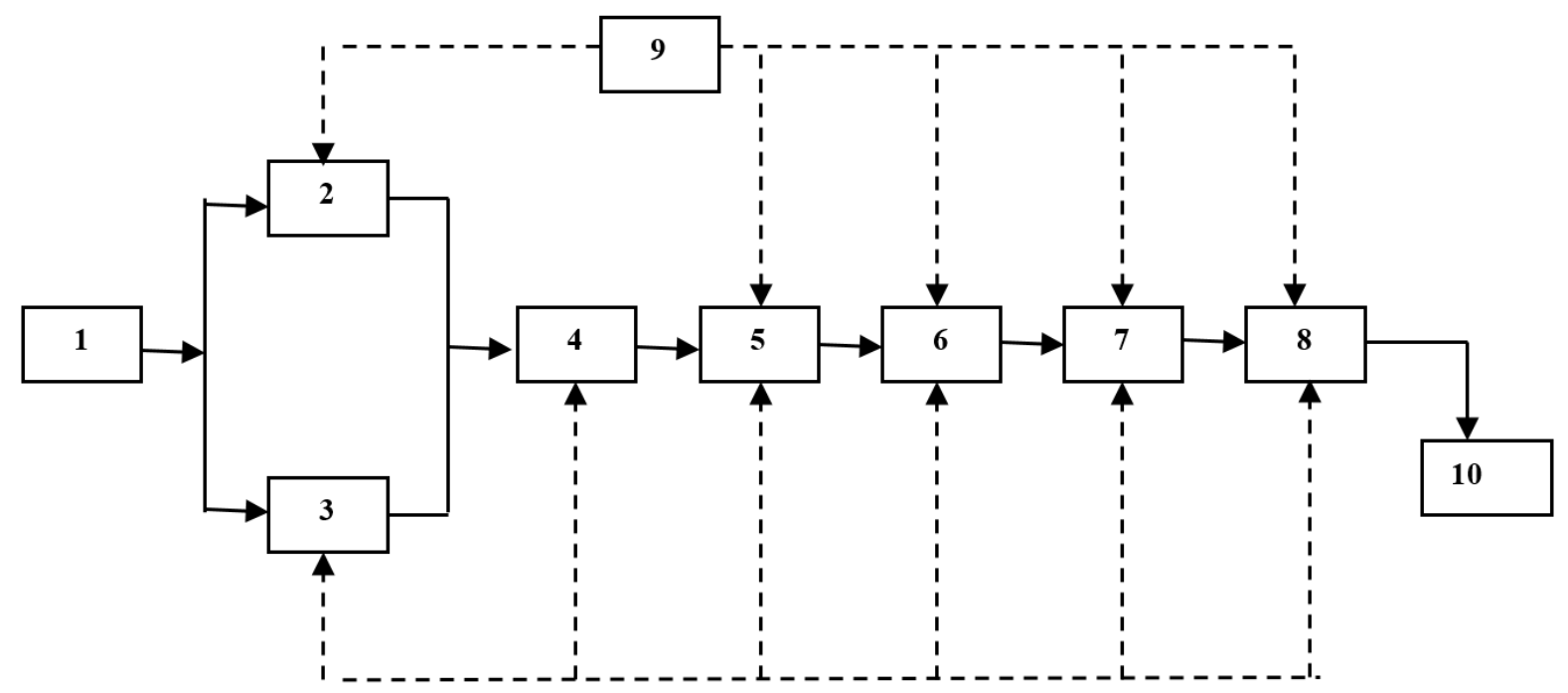

Figure 1. Chart of the Dick \& Carey model 
4) There is a dice which is a nominal number to guide the number of steps in the game. Dice consists of 2 pieces. The first dice contains negative numbers $(-1,-1,-2,-2,-3,-3)$ and dice 2 contains positive numbers $(4,5,6,4,5,6)$. This is as an exercise in calculating algebra in mathematics.

5) Regional cards totaling 18 areas from initially totaling 36 areas. Naming areas are adjusted to the material in mathematics class VI.

6) Behind the area card there are questions that must be worked on, which initially are the nominal price that must be paid by other players.

7) Money in the monopoly game there are 3 types $(1,3,5)$ which initially there are 9 (usually) 100, 500, 1000, 2000, $5000,10000,20000,50000,100000)$. Money here is used as points.

8) Chance card and general funds are changed to an empty hour card and go home quickly. Both of these are chosen because if the hours are empty or go home early then students will be given training (homework) by the teacher.

9) The card goes home quickly and the blank hour behind it contains the questions students have to do.

10) This monopoly is named: MONOPOLI AMIS (Ask Math In School)

b. The making of monopoly equipment consists of several stages:

1) Making a monopoly board design, area certificate, game money on used paper until an appropriate design is formed.

2) Look for materials related to monopoly boards such as pictures from the internet.

3) The design was applied in the CS3 Photoshop computer program. The following are the results of the board design

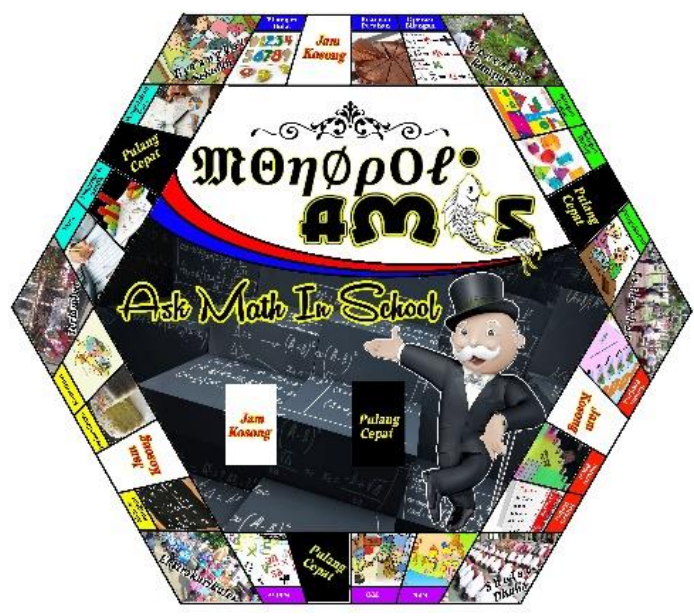

Figure 2. Monopoly board games

1) Area certificate, blank hour card and fast return card there are two sides, the front side has the name and picture according to what is on the game board, on the back there are practice questions.

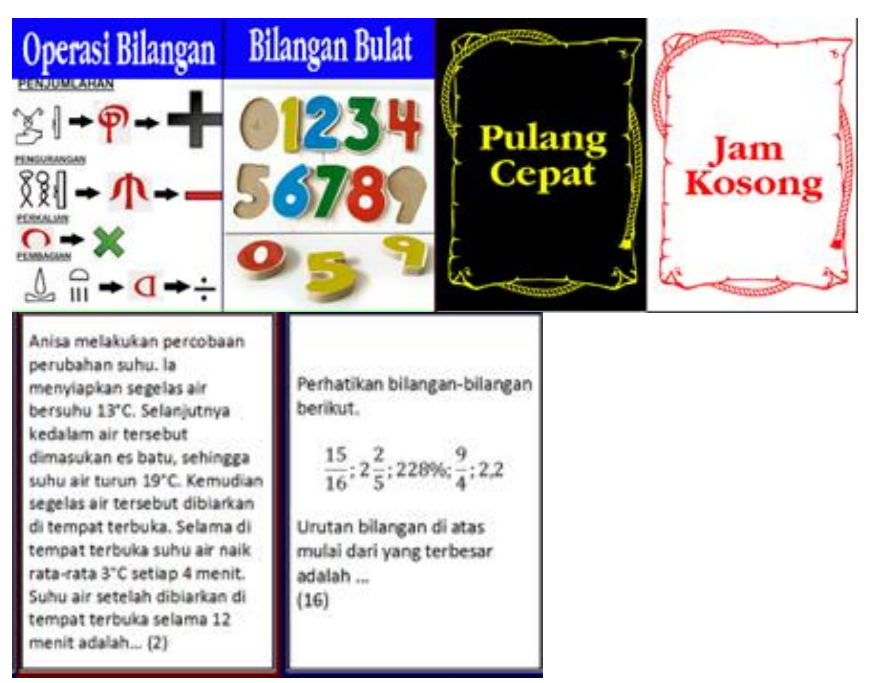

Figure 3. Front side, back side of the question exercise

2) Game money consists of 3 types.
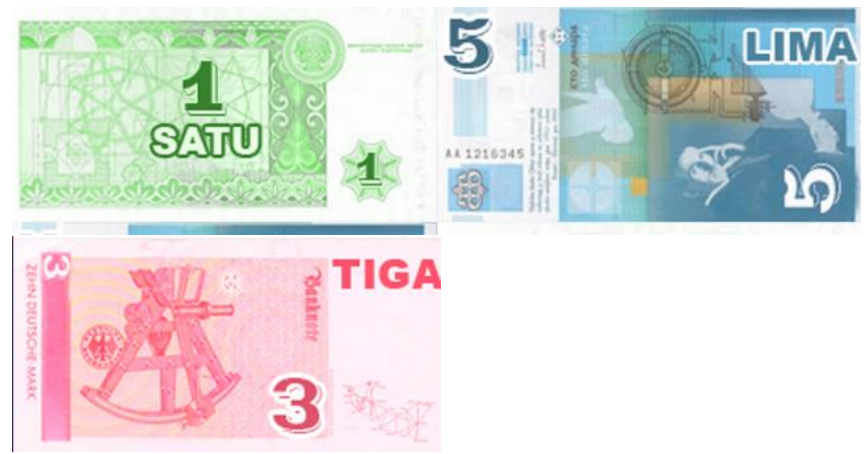

Figure 4. Game money

3) The pieces consist of 5 different shapes. Pawn can use other objects whose dimensions are not too large.

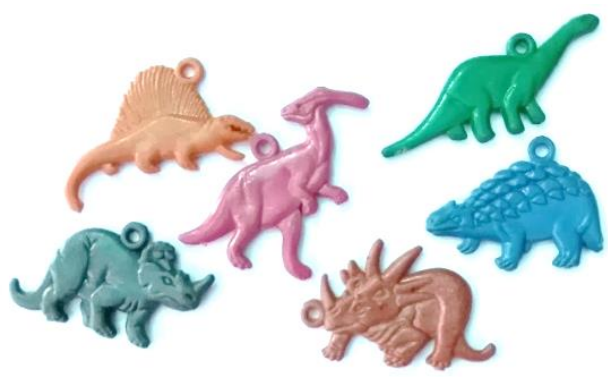

Figure 5. Game piece

4) The dice consists of 2 , negative numbers and positive numbers.

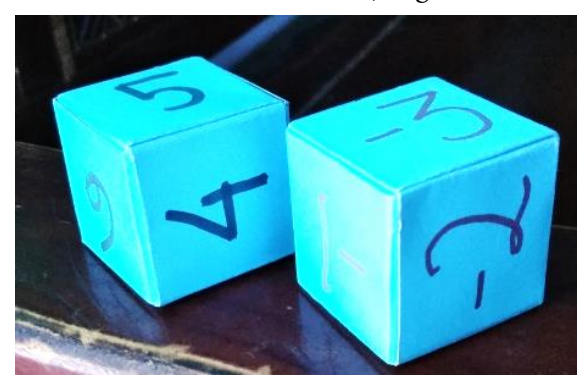

Figure 6. Dice game

5) Making and manipulation of actual monopoly boards.

\section{Design and conduct formative evaluations}

Namely the evaluation carried out by the developer during the process, procedure, program or product developed. This formative 
evaluation can be done when learning takes place for the process of increasing effectiveness.

a. One-to-one trying out

- Giving points at the beginning will use stars (from paper) or use beads, but will require a large amount so that it is changed in the form of a kind of play money like in a monopoly.

- The dice are number one because to limit the step, it is changed to 2 by changing the number of the dice.

- The width of the game board area of A3 paper is changed to 2 times $\mathrm{A} 3$ so that it is clearer and wider in the game.

- Not all chapters in mathematics are included in game boards, such as roman numerals, only those contained in the national exam grid.

This trial is conducted to obtain initial input about a particular product or design. Individual trials conducted on subjects 1-3 people. After an individual trial, the product or design is revised.

b. Small group tryout

This trial involves subjects consisting of 6-8 subjects. The results of this small group trial are used to make product or design revisions.

- The number of supervisors is adjusted according to the number of students in the class

- 1 round of game is not too fast and not too long, the supervisor has the right to reprimand / remind, adapted to the work on the questions on the national exam. 40 questions for 120 minutes, so 1 question averaged 3 minutes.

\section{c. Field tryout}

\section{Field trial process}

This trial involved subjects in a larger class involving $15-50$ subjects (a whole class of learners).

- The game area (classroom) is suitable for all games, not spread in several places.

- Selection of players in the form of individuals or groups tailored to the character of students.

\section{Make revisions}

Revisions are made to the learning process, procedures, programs, or products associated with the previous steps. The revision is made to produce the points contained in step number 7 .

\section{Summative evaluation}

After a product, program, or development process is completed, the next step is to conduct a summative evaluation. Summative evaluations are carried out with the aim of determining the overall effectiveness of the product, program, or process compared to other programs. To produce effective results it takes:

- More than 1 teacher, or 3 group games 1 teacher

- Minimum number of supervisors is 2 if possible.

- The game set is duplicated so that the game can be used with individual players (not in groups)

- Try to play a large game room and will not disturb the next room

\section{CONCLUSIONS AND SUGGESTIONS}

\section{Conclusions}

This study aims to produce media that are suitable for use in the learning process and at the same time be able to improve student learning outcomes in Mathematics subjects in grade VI Elementary Schools as a form of national exam preparation. This monopoly game can be used in try-out activities.

\section{Suggestions}

Based on the results of research and conclusions, this monopoly game media researchers submit some useful suggestions for better product development.

1. The results of the development of this learning media can be developed again in terms of design development, so that the level of meaningfulness in the use of learning media is increasing with innovations in accordance with technological developments.

2. This monopoly game media can be developed in other subjects by developing various concepts of subjects to be designed therein.

3. To improve the quality of learning in the classroom, teachers can combine media monopoly games with learning models that are considered more efficient and student-centered so that learning activities become more meaningful, varied, and enjoyable.

\section{REFERENCES}

Arikunto, S. (2009). Dasar-Dasar Evaluasi Pendidikan [Basics of Educational Evaluation]. Jakarta: Bumi Aksara.

Arya, dkk. (2009). Metamorfosa Bukan Sekedar Nama [Metamorphosis Is Not Just a Name]. Matan Ed. 36, July 2009.

BSNP, Prosedur Operasi Standar Ujian Nasional Sekolah [Standard Operating Procedure for School National Examination].

Daryanto. (2010). Media Pembelajaran [Learning Media]. Yogyakarta: Gava Media

Firdaus, Z., Zubaidah, S., \& Sunarmi. (2015). Pengembangan Media Pembelajaran Monopoli IPA Materi Sistem Pencernaan Makanan untuk Siswa Kelas VIII Di SMP Negeri 4 Malang [Development of Natural Science Monopoly Learning Media for Digestive System Material for Class VIII Students at SMP Negeri 4 Malang]. Ilmu Hayati, Unirsitas Negeri Malang, 1(1).

Gay, L. R. (1991). Educational Evaluation and Measurement: Com-petencies for Analysis and Aplication (2nd. Ed.). New York: Macmillan Publishing Company.

Hakim, F. N. (2012). Hubungan Antara Kesiapan Mengikuti Tes Ujian dengan Prestasi Belajar Mata Pelajaran Produktif Siswa SMK N 3 Wonosari [The Relationship Between Readiness to Take Examinations and Learning Achievement of Productive Subjects in SMK N 3 Wonosari Students] (Unpublished Thesis). Program Studi Pendidikan Teknik Boga Jurusan Pendidikan Teknik Boga dan Busana Fakultas Teknik Universitas Negeri Yogyakarta. 
Husna, A. M. (2009). 100+ Permainan Tradisional Indonesia: Untuk kreativitas, ketangkasan dan keakraban [100+ Traditional Indonesian Games: For creativity, dexterity and familiarity]. Jakarta: Andi Publisher

Lubis, H. Z., \& Harahap, A. (2015). Penggunaan Media Monopoli dalam Meningkatkan Hasil Belajar Akuntansi Siswa. Prosiding Seminar Nasional Pendidikan Akuntansi dan Keuangan: "Pengembangan Pendidikan Akuntansi dan Keuangan yang Berkelanjutan"[Proceedings of the National Seminar on Accounting and Finance Education: "Sustainable Development of Accounting and Finance Education"]. Universitas Negeri Surakarta.

Musfiqon. (2012). Pengembangan Media dan sumber Pembelajaran [Media Development and Learning Resources]. Jakarta: Prestasi Pustaka.

Prayogo, B. A. (2017). Pengembangan Permainan Monopoli sebagai Media Pembelajaran Matematika pada Siswa Kelas II SDN Langensari 02 Kecamatan Ungaran Barat [Monopoly Game Development as a Mathematics Learning Media in Class II Students of SDN Langensari 02, West Ungaran District] (Unpublished Thesis). Jurusan Pendidikan Guru Sekolah Dasar Fakultas Ilmu Pendidikan Universitas Negeri Semarang.

Sadiman, A. S. (2009). Media Pendidikan: Pengertian, Pengembangan dan Pemanfaatannya [Educational Media: Definition, Development and Utilization]. Jakarta: Rajawali Press.

Santoso, A. (2018). Profil Kesiapan Siswa dalam Menghadapi Ulangan Harian pada Siswa Kelas XI Di SMA Negeri 2 Sukoharjo Tahun Ajaran 2017/2018 [Profile of Student Readiness in Facing Daily Test in Class XI Students at SMA Negeri 2 Sukoharjo Academic Year 2017/2018] (Unpublished Thesis). Program Studi Pendidikan Akuntansi Fakultas Keguruan dan Ilmu Pendidikan Universitas Muhammadiyah Surakarta.
Seels, B. B., \& Richey, R. C. (1994). Teknologi Pembelajaran: Definisi dan Kawasannya [Learning Technology: Definition and Its Areas]. D. S. Prawiradilaga et al. (trans.). Jakarta: Kerjasama IPTPI LPTK UNJ.

Slameto. (2003). Belajar dan Faktor-Faktor yang Mempengaruhinya [Learning and the Factors That Affect It]. Jakarta: PT Rineka Cipta.

Soeharto, K., et al. (2003). Teknologi Pembelajaran Pendekatan Sistem, Konsep, dan Model, SAP, Evaluasi, Sumber Belajar dan Media [Learning Technology Systems Approach, Concepts, and Models, SAP, Evaluation, Learning Resources and Media]. Surabaya: SIC.

Sudrajat, H. (2004). Implementasi Kurikulum Berbasis Kompetensi [Implementation of Competency-Based Curriculum]. Bandung: Cipta Cekas Grafika

Sukiman. (2012). Pengembangan Media Pembelajaran [Learning Media Development]. Yogyakarta: PT. Pustaka Insan Madani.

Sukismo, et al. (n.d.). Erlangga Fokus UN SMP/MTs 2014. Jakarta: Erlangga.

Suryabrata, S. (2001). Psikologi Pendidikan. Jakarta: Raja Grafindo Persada.

Susanto, A., Raharjo, \& Prastiwi, M. S. (2012). Permainan Monopoli sebagai Media Pembelajaran Sub Materi Sel pada Siswa SMA Kelas XI IPA [Monopoly Game as Learning Media for Cell Sub Material in Class XI IPA High School Students]. BioEdu, 1(1).

Try Out (2014). Unas penting untuk digelar sebagai persiapan dan tolok ukur sekolah [Unas is important to be held as a preparation for school benchmarks]. Retrieved on 31 September 2019 from http://www.SragenNews.online html edition.

Waldjinah, et al. (2013). Seconds - Seconds of the 2013/2014 Academic Year National Examination. Yogyakarta: PT. Intan Pariwara. 